\title{
TEACHING MATERIAL DEVELOPMENT \\ "PRACTICAL GUIDELINES FOR READING AL-QUR'AN" \\ IN LEARNING AL-QUR'AN \\ AT GRIYA AL-QUR'AN OF SURABAYA
}

\author{
Khoirul Huda ${ }^{1}$ Mahsun Jayadi ${ }^{2}$ \\ Khoirulhuda84@gmail.com¹ mahsun_umsby@gmail.com²
}

\begin{abstract}
The manuscripts of Qur'an that are scattered around us are divided into 2 types i.e. Indonesian standard manuscripts and the Middle East or Madinah standard, the development of these two manuscripts is not balanced with the refining of teaching materials or the Qur'anic learning method, $90 \%$ of the methods refer to Indonesian standard manuscripts and the rest refer to Mushaf Madinah. This challenge was answered by the Griya Al-Qur'an to provide a method that refers to the Mushaf Madinah which has been running for 7 years and has printed 14,000 books that should have been revised as soon as the input from the user (asatizah). The three problems became the study of this thesis. First, how to describe the learning of the Qur'an? Second, how to develop teaching material? And third what is the effectiveness of teaching materials?. This study used an R \& D approach or in practice mixed between qualitative and quantitative, qualitative to measure the depth of the material as well as quantitatively to measure validity and effectiveness of teaching materials. The results of the study were as follows: First, the Qur'an Learning should pay attention to 7 components of learning namely goals, material, students, teachers, methods, tools and assessment systems. Second, to develope this teaching material, the ADDIE stage was analyzed, the results of which were revised focus on adding volume 1 and changing the paper size, designed by making a re-design of the material based on the analysis results and preparing the Mushaf Madinah printing software with the Usmani hafs V09 font, Development by implementing what has been designed and invited material experts and instructional media experts
\end{abstract}


to test validity with the results of the experts' values of $80 \%$ and $76 \%$, respectively, which meant valid. The third was to measure effectiveness through the implementation stage by conducting a trial with the pretest result of $33 \%$ and posttest of $79 \%$ which meant that this teaching material was effective and ended with evaluation by evaluating each stage of development.

Keywords: Teaching materias Development , Griya Al-Qur'an, Qur'an Learning

\section{A. INTRODUCTION}

Qur'anic learning has begun since the time of the Prophet. Every time the prophet gets revelation the prophet gathers his friends to deliver the revelation and teach its contents. At the time of the Prophet known as the Majlis al-Rasul.1

There are various ways in which we can understand the Qur'an, from how to read, translate, memorize and how the Al-Qur'an becomes the rule of daily life. A small example of the method of learning to read the Al-Qur'an in Indonesia which has experienced tremendous development, both those that have not been structured or that have already been, which in essence would further facilitate the Indonesian community in learning the Al-Qur'an.

In addition to many methods, it also has an effect on Qur'anic learning institutions such as TPQ, which are required to always maintain quality and choose the method of reading the Al-Qur'an that is suitable for the purpose of the TPQ, one of which is Griya Al-Qur'an Surabaya which seeks to form a curriculum for adults to help local communities.

In the development of the curriculum, Griya Al-Qur'an has made several changes, established in 2006 which was originally called Rumah Qur'an, by making Tahfidz the main program, the teaching material used is the Al-Qur'an itself, starting in the House of the Qur'an metamorphosed into the Qur'an and the program also developed, starting from how to read the Al-Qur'an from zero, learning the rules of recitation until memorizing the Al-Qur'an 30 juz.

\footnotetext{
1 "Majlis al-rasul" merupakan suatu majlis atau tempat yang digunakan oleh nabi untuk menyampaikan wahyu kepada para sahabat. Setiap kali nabi menerima wahyu, beliau menyampaikan kepada para sahabat melalui majlis-majlis tersebut.
} 
The willingness of the community to return to the Al-Qur'an is very large, as evidenced when there are 150 new registrants who come to register on average every 3 months. ${ }^{2}$ When prospective students are asked about their learning motivation that they answer because they cannot read the Al-Qur'an well. ${ }^{3}$ The answer was reinforced by the results of a survey which said that although Indonesia was the largest Muslim majority country in the world, only about 0.5 percent of Muslims in Indonesia are able to read the Al-Qur'an well. ${ }^{4}$ And sharpened again. The survey results of the Institute of Qur'anic Sciences (IIQ) in Jakarta stated that 65 percent of Muslims in Indonesia were still illiterate in the Al-Qur'an. 35 percent can only read the Al-Qur'an. Whereas those who read correctly are only 20 percent. $^{5}$

Various teaching materials (methods) are spread in the midst of the community and are divided into 2 references,

1. The method that uses references to Indonesian manuscripts, this method began with the birth of the book of baghdadiyah or often we call it Turutan from Baghdad during the reign of the Abbasid Caliphs. We do not know for sure who the compiler is. Moreover it has been developing for more than a century in the country. ${ }^{6}$ Then a similar method emerged such as Method Gabriel, Iqra', Qiroati, Tilawati, Al Barqy, Yanbua and others.

2. The method that uses references to the Mushaf of Medina or Beirut (Middle East), which is the Qur'an that we often find when performing Umrah or Hajj and is usually a gift for worshipers when they want to leave tanah haram. Very few methods refer to Mushaf Madinah, one of which is the Ottoman method by Ust Efendi anwar from Depok besides that there is another but not yet developed.

\footnotetext{
${ }^{2}$ Dokumen Griya Alquran, Hasil placementes siswa Griya Alquran Surabaya, 2017.

${ }^{3}$ Imam Masruri (General Manager), wawancara, Surabaya, 24 Oktober 2017.

4 Saiful Bahri, (Ternyata Hanya 0,5 Persen Masyarakat Indonesia yang Bisa Baca Al-Quran), dalam https://www.dakwatuna.com/2014/06/16/53213 (24 Oktober 2017) .

${ }^{5}$ Muhammad Amed, (Buta Huruf Alquran di Indonesia, Sungguh Menyedihkan), dalam https://www.kompasiana.com/alwaysmuhammad ( 24 Oktober 2017).

${ }^{6}$ Ida Vera Sophya \& Saiful Mujab, Metode Baca Qur'an, Jurnal Elementary, Vol 2, (2014), 2.
} 
The imbalance in the development of the methods from the two references above has become a problem, many Indonesian Umrah or Haj pilgrims find it difficult to read the Al-Qur'an when they are in tanah haram to become a major problem, while the method that refers to the Mushaf of Medina is very little and almost non-existent for the East Java area in particular. Therefore it is from Griya Al-Qur'an that is challenged to answer it by making teaching materials focus on introducing the way of reading the AlQur'an by using the Mushaf Madinah approach by writing a basic guidebook for reading the Al-Qur'an.

The challenges above are not only aimed at one institution but the position of Islamic education, as stated in Law Number 2/1989 concerning the National Education System, which implicitly shows the nation's recognition of the great contribution of Islamic education in the effort to educate and make smart the nation. This recognition, according to Moch Tolchah, is a challenge that requires a positive response from thinkers and managers of Islamic education to further improve its quality, both in the face of increasingly high demands for mastery of science and technology as well as the need for stabilizing and practicing religious teachings. ${ }^{7}$

Initiation to make the method itself has the support of various parties, the development of teaching materials is included in the realm of curriculum development or curriculum sequencing in the standard content stage, there are several curriculum development models, one of which is the Grass roots model, namely curriculum development efforts rather than coming from above but come from below, asatizah as the user of the teaching material. ${ }^{8}$

Precisely in 2011 the first book was published and has undergone two revisions, in the first issue the basic guidebook was written by hand or manually, from the evaluation of its development it was considered that the font quality was less neat and less clear when read, so in 2013 the revision was done by cursing the software the results of which can answer previous deficiencies.

\footnotetext{
${ }^{7}$ Moch Tolchah, Filsafat Pendidikan Islam:Konstruksi Tipologis dalam Pengembangan Kurikulum, Jurnal Tsaqafah, Vol II No 2, (November 2014), 392-393.

${ }^{8}$ Nana Syaodih Sukmadinata, Pengembangan Kurikulum Teori dan Praktik (Bandung: PT Remaja rosda karya, 2015),162.
} 
2013 to 2016 the revised book has been used and reaped positive results, but there are still deficiencies that are felt to be resolved immediately, then formulated deficiencies such as the structure of the material sequence that is not yet coherent and the size of the book, fonts and guides teaching each page. Revisions should be made so that effectiveness in the learning of the Qur'an at the Griya Al-Qur'an is maintained.

Effectiveness in learning the Al-Qur'an at the Griya Al-Qur'an has been said to be effective because it is in accordance with the principles conveyed by Faustini Cardoso Gomes, but in the realm of effectiveness of teaching materials that have been done are not effective yet, it can be seen from the lack of a standard cover, coherent sequences and material order, in words otherwise, the standard development model has not been implemented by the Griya Al-Qur'an and if there is a need for immediate improvement.

The problems that will be solved through this research are:

1. How is the description of Al-Qur'an learning?

2. How is the Development of Teaching Materials "Practical Guidelines for Reading the Al-Qur'an" in the Al-Qur'an Learning at the Griya Al-Qur'an?

3. How is the Effectiveness of Teaching Materials "Practical Guidelines for Reading the Al-Qur'an" in the Al-Qur'an Learning at the Griya Al-Qur'an?

\section{B. RESEARCH METHODS}

The method of Research and Development is a research method used to produce certain products, and test the effectiveness of these products.

This research was conducted at a Qur'anic Learning Institute, the Griya Al-quran Surabaya, this location was taken on the basis of the researchers' first consideration because the institution used teaching materials that would become the object of the researcher.

Data sources and collection techniques of this research are: Primary sources interview direct General Manager, Branch Manager and Asatidzah Griya Al-Qur'an, as well as the authors themselves because part of the organ of the institution, Secondary sources are taking from the documentation of policy results or meeting notes.

The data analysis technique is one of the stages in a study. Data analysis is carried out when and after a set of facts or information is obtained through several data collection 
techniques. According to Bogdan and Taylor, data analysis is a process that specifies a formal effort to find themes and formulate working hypotheses (ideas) as suggested by the data and as an effort to provide assistance on themes and hypotheses. ${ }^{9}$

1. Analysis of qualitative data

In this study the analyzed data collected in interview transcripts, field notes and documents. The stages in this analysis are checking, checking data transcripts of observation interview data, existing documents, and Organizing (grouping), Data grouping is done by sorting out or classifying data according to the direction of the research focus.

2. Quantitative data analysis

This analysis technique based on the validation questionnaire data obtained, the formula used to calculate the results of the questionnaire from the validator is as follows:

$$
P=\frac{\sum x}{\sum x_{i}} \times 100 \%
$$

Where

$P=$ Percentage sought

$\sum x=$ Number of respondent's answer values

$\sum x_{i}=$ Number of ideal value

While as a basis for making decisions to revise teaching materials used assessment criteria are adapted from the Education Evaluation basics book as follows:

Tabel 3.1

Validation Criteria

\begin{tabular}{|c|c|}
\hline Persentase (\%) & Validasi Criteria \\
\hline $76-100$ & Valid \\
\hline $56-75$ & Cukup Valid Enough \\
\hline $40-55$ & Less Valid \\
\hline $0-39$ & Invalid \\
\hline
\end{tabular}

\footnotetext{
${ }^{9}$ J. Moleong,Lexy,Metodelogi Penelitian Kualitatif(Bandung: Remaja Rosda Karya), 2008, 280.
} 
The development model in this study is defined as a conceptual framework used as a reference in carrying out activities, according to Briggs model is a set of sequential procedures to realize a process. ${ }^{10}$ The development design model in this study refers to the research and development in design of ADDIE developed by Reiser and Mollenda stands for Analysis, Design, Development or Production, Implementation or Delivery, an Evaluation.

\section{ANALYSIS DISCUSSION AND RESEARCH RESULTS}

\section{The Qur'anic Learning Process at the Griya Al-Qur'an}

a. Learning objectives

The goal in the learning process is a crucial process that is the component that must be determined that functions as the main of Key Performa Indication (KPI). This goal is basically a competency that must be achieved and possessed by students at the end of learning activities. The contents of the actual learning objectives are what is expected from the results of a learning that has general and special characteristics, generally covering 3 types.

1) Cognitive purpose, or scientific nature and way of thinking.

2) Affective goals, or motivational in learning.

3) Psychomotor goals, or are of a nature with the skill in learning. ${ }^{11}$

Table 1

Program Purpose

\begin{tabular}{|l|l|l|}
\hline NO & PROGRAM & \multicolumn{1}{|c|}{ Purpose } \\
\hline 1 & TAHSIN & $\begin{array}{l}\text { To master the basic competencies of } \\
\text { reading the Al-Qur'an, especially from } \\
\text { aspects of practical theory. }\end{array}$ \\
\hline 2 & TARTIL & $\begin{array}{l}\text { To improve the basic competencies of } \\
\text { reading the Al-Qur'an both theoretically } \\
\text { and practically covering aspects of } \\
\text { makharijul alphabet (pelafadzan/how to }\end{array}$ \\
\hline
\end{tabular}

${ }^{10}$ Trianto, Metode Pembelajaran Terpadu, (Jakarta: Prestasi Pustaka, 2007), 53.

${ }^{11}$ Ahmad Rohani dan Abu Ahmad, Pengelolaan Pengajaran, (Jakarta: Rineka Cipta, 1991), 100. 


\begin{tabular}{|l|l|l|}
\hline & & $\begin{array}{l}\text { pronounce the alphabet), tajwid, gharibul } \\
\text { qira'ah, waqaf ibtida 'and smooth reading. }\end{array}$ \\
\hline 3 & TAHFIDZ & $\begin{array}{l}\text { To memorize the Qur'anic verses starting } \\
\text { juz } 30 \text { then juz 1 and later. }\end{array}$ \\
\hline 4 & $\begin{array}{l}\text { TAFHIM/ } \\
\text { TAFSIR }\end{array}$ & $\begin{array}{l}\text { To understand the verses of the Qur'an and } \\
\text { take lessons / wisdom contained in them. }\end{array}$ \\
\hline 5 & $\begin{array}{l}\text { TEACHER } \\
\text { CERTIFICA } \\
\text { TION }\end{array}$ & $\begin{array}{l}\text { To prepare the Qur'anic teachers who are } \\
\text { competent both in the professional, } \\
\text { pedagogical, personal and social aspects. }\end{array}$ \\
\hline
\end{tabular}

b. Learning Materials

The learning material is prepared or chosen in the hope that it can add color to the learning objectives, and can support the achievement of the goals or competencies expected by students.

Table 2

Basic Competencies of Tahsin

\begin{tabular}{|c|c|c|}
\hline NO & CORE COMPETENCE & BASIC COMPETENCIES \\
\hline 1 & $\begin{array}{l}\text { Science } \\
\text { Mastering the basics of } \\
\text { reading the Al-Qur'an }\end{array}$ & $\begin{array}{l}\text { a. Knowing the names - } \\
\text { hijaiyah letters and various } \\
\text { harakat names } \\
\text { b. Knowing long signs, sukun } \\
\text { and tasydid } \\
\text { c. Knowing the sign of hum, } \\
\text { waqaf and gharib verses }\end{array}$ \\
\hline 2 & $\begin{array}{l}\text { Skills } \\
\text { Demonstrating Quran } \\
\text { recitations with tartil. }\end{array}$ & $\begin{array}{l}\text { a. Skilled in reading hijaiyah } \\
\text { letters and their harokat. } \\
\text { b. Skilled in reading long } \\
\text { readings, sukun and } \\
\text { Tasydid } \\
\text { c. Skilled in reading hum, } \\
\text { waqaf and grarib verses }\end{array}$ \\
\hline
\end{tabular}


c. Teacher / Asatidzah

The teacher is an important place, whose existence is a determinant of the success of educators and facilitator.. The task of the teacher or ustadz in general is to develop the full potential of students to the maximum, of course by looking at Islamic religious norms, in reducing the potential of all domains it is not easy to be a religious teacher must have high responsibility.

Griya Al-Qur'an teacher standards are as follows:

1) Memorize at least $15 \mathrm{Juz}$

2) Minimum Senior High School especially under graduates or S1

3) Having broad Islamic insights

d. Student / Santri

Students are objects or anyone who receives influence from individuals or groups of people who carry out the learning process, students are important human elements in educative interaction activities, they are subjects as the problems in all forms of educational and teaching activities, students are components that if there is no educational activity will not happen..

The target of the program or is the student at Griya Al-Qur'an is a minimum of 17 years with a background of students (students and college students), professionals, and the general public.

e. Learning methods

The teaching method is the method used by the teacher in delivering the material so that it can be accepted by students well. Griya Al-Qur'an uses the SUBUH process approach.

Table 3

Standar Process

\begin{tabular}{|c|c|c|}
\hline NO & PROCESS & ACTIVITY \\
\hline 1 & SALAM & $\begin{array}{l}\text { a. Open learning activities with greetings } \\
\text { and prayers. } \\
\text { b. The teacher reads the list of students } \\
\text { present. } \\
\text { c. The teacher conveys learning motivation. }\end{array}$ \\
\hline
\end{tabular}




\begin{tabular}{|c|c|c|}
\hline & & $\begin{array}{l}\text { d. The teacher conveys the goals / indicators } \\
\text { to be achieved. }\end{array}$ \\
\hline 2 & REPEAT & $\begin{array}{l}\text { a. The teacher asks students to repeat the old } \\
\text { material together or individually. } \\
\text { b. Students repeat the old material according } \\
\text { to the teacher's instructions. } \\
\text { c. The teacher associates old material with } \\
\text { new material. }\end{array}$ \\
\hline 3 & GIVE IT & $\begin{array}{l}\text { a. The teacher gives an example of tartile } \\
\text { new material readings. } \\
\text { b. Students listened then imitated the } \\
\text { teacher's reading tartile. } \\
\text { c. The teacher leads students to find / } \\
\text { understand the rules of reading. } \\
\text { d. Students read new material alternately in } \\
\text { teacher supervision. }\end{array}$ \\
\hline 4 & TEST & $\begin{array}{l}\text { a. Students read new material then tadarus } \\
\text { Al-Qur'an. } \\
\text { b. The teacher assesses students' reading } \\
\text { skills. }\end{array}$ \\
\hline 5 & $\begin{array}{l}\text { HAMDAL } \\
\text { AH }\end{array}$ & $\begin{array}{l}\text { a. The teacher helps students conclude the } \\
\text { material. } \\
\text { b. The teacher delivers follow-up material. } \\
\text { c. The teacher conveys learning motivation. } \\
\text { d. Closing learning activities with prayer and } \\
\text { greetings. }\end{array}$ \\
\hline
\end{tabular}

f. Teaching Tools

Teaching tool is a tool to reach a teaching goal, Griya Al-Qur'an divides it into 2 categories

1) Teaching tools that are individual in nature, namely the tools used by students or teachers, such as learning books, books, mutabaah and so on. 
2) Classic teaching tools, namely teaching tools used by all teachers and students and used together such as white boards, markers and so on.

g. Assessment

Winarno Surahkman explained about the assessment that is an activity to measure the level of progress and mastery of students, including assessment of student learning outcomes in aspects of attitude and willingness, and skills. ${ }^{12}$

Table 4

Tahsin and Tartil Scale values

\begin{tabular}{|c|c|}
\hline VALUE & INFORMATION \\
\hline $90-95$ & $\begin{array}{l}\text { a. Applying the reading law } \\
\text { appropriately, perfectly (firmly) and } \\
\text { smoothly. } \\
\text { b. There is no jali (clear) or khafi } \\
\text { (vague) error. }\end{array}$ \\
\hline $80-85$ & $\begin{array}{l}\text { a. Applying the reading law } \\
\text { appropriately and smoothly but not } \\
\text { perfectly (less firm). } \\
\text { b. There are lahn (errors) khafi (vague) } \\
\text { maximum } 3 \text { and there is no lahn } \\
\text { (error) jali (obviously). }\end{array}$ \\
\hline $70-75$ & $\begin{array}{l}\text { a. Applying the reading law } \\
\text { appropriately but not smoothly and } \\
\text { less firmly. } \\
\text { b. There are lahn (errors) khafi (vague) } \\
\text { more than } 3 \text { errors and lahn (errors) } \\
\text { jali (obviously) a maximum of } 3 \\
\text { errors. }\end{array}$ \\
\hline $60-65$ & $\begin{array}{l}\text { a. Cannot apply the reading law } \\
\text { appropriately and or memorize it. } \\
\text { b. There is a number of errors } \\
\text { (obviously) more than } 3 \text { errors. }\end{array}$ \\
\hline
\end{tabular}

${ }^{12}$ Winarno Surakhman, Pengantar Pendidikan Ilmiah, (Bandung: Tarsito, 1985), 147. 
h. Evaluation in Learning Al-Qur'an

Griya Al-Qur'an has 2 types of evaluation, namely daily is usually at the end of the trial (Post Test). This evaluation is carried out with the task of reading directly in front of the ustadz as well as input for students if there are deficiencies, as well as periodic evaluations which are carried out at the end of the learning period (10 weeks) tested by senior ustadz

\section{Development of Teaching Materials "Practical Guidelines for Reading the Qur'an"}

a. Analyze is taken from the results of the Griya Al-Qur'an teachers' workshop in East Java as follows: ${ }^{13}$

1) Basis 1, addition of kasrah dhammah gift material, continued stacking

2) Basic 2, practice connecting 2 sentences

3) Basic 3, separate training with dengug

b. Design

1) Preparing the design of teaching materials

2) Preparing supporting materials such as determining the content of the sample paragraphs that were replaced, the font selection of Mushaf Madinah, the Uthmanic Hafs V09 font and the Al Madinah Mushaf Software An Nabawiyyah Lin Nasyri al Hasubi issued by King Fahd The Glorious Quran Printing Complex (KFGQPC) is the right choice.

\section{Gambar 1}

\section{Mushaf Madinah Software}

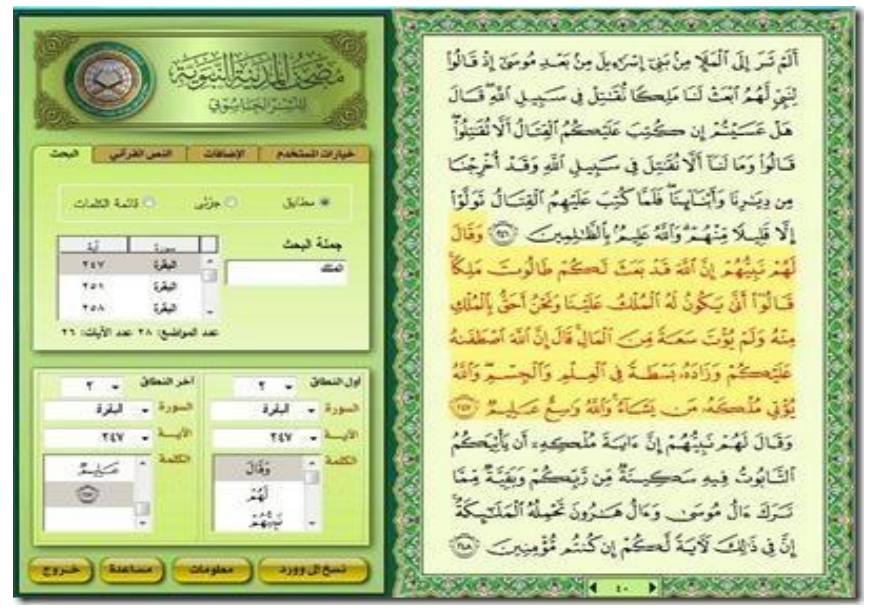

${ }^{13}$ Dokumen Workshop Griya Alquran Surabaya, tahun 2014, 11 


\section{c. Development}

1) The general revision

The general revision is the overall revision of volumes 1 through 3 , especially in display layouts such as cover, size $(16.5 \times 21.5 \mathrm{CM}$ to $17.5 \times 25 \mathrm{CM})$, continuous numbering, border design, content standard at the beginning of each volume and addition of conclusion sentences in the bottom page

Table 6

\section{Conclusion sentence}

\begin{tabular}{|c|c|}
\hline Before Revision & After Revision \\
\hline Nothing & 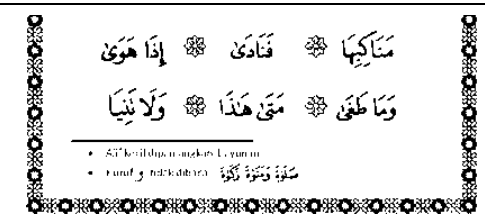 \\
\hline
\end{tabular}

2) Special revision

Special revisions are revisions that focus on changes or additions to the material

a) Pre Material includes changes in learning stages, addition of names of hijaiyah letters and arabic numbers.

b) Volume 1 includes the addition of material Yes at the end of the non-dotted series, the stacked letters, Introduction to Harakat Kasrah and Dlommah

Table 7

Connect Stack

\begin{tabular}{|c|c|}
\hline Before Revision & After Revision \\
\hline Nothing & 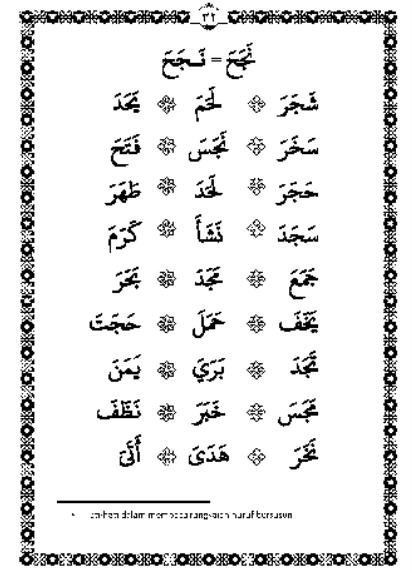 \\
\hline
\end{tabular}


c) Volume 2 includes the neatness of the example line, the two-sentence connection exercise, replacing the concept of the example of the sukun and syiddah material and adding an example 3 more sentences

Table 8

Line Neatness

\begin{tabular}{|c|c|}
\hline Before Revision & After Revision \\
\hline 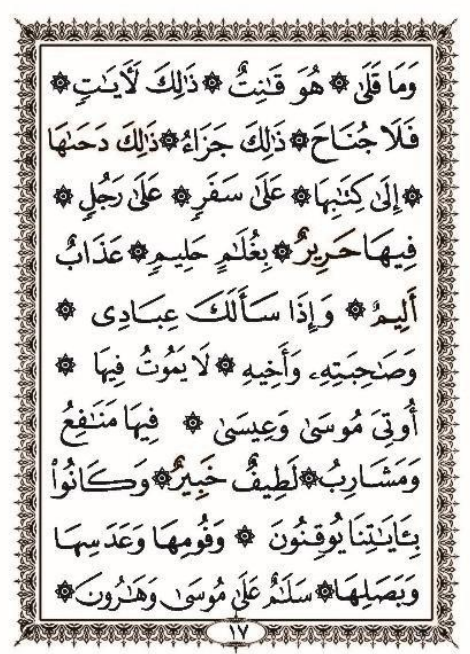 & 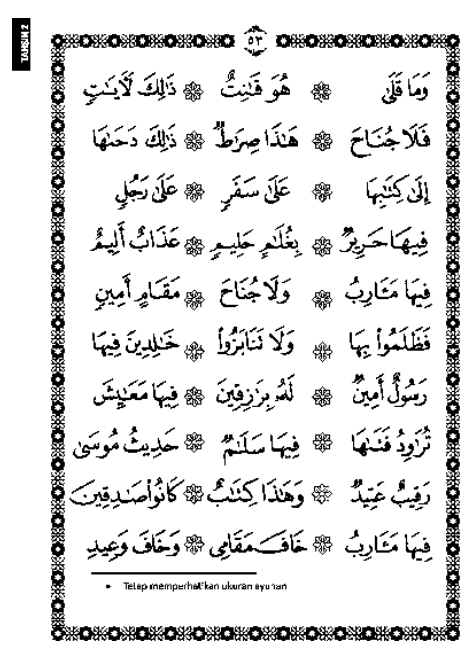 \\
\hline
\end{tabular}

d) Volume 3 includes separating non-marking Nun material and tanwin slant 99, adding material when the waqaf haha, changing the concept of Hamzah Washal at the beginning of the sentence with the concept of Honest Characteristics of Faith.

3) Expert Assessment 1

a) Expert Material Assessment

Expert validation, namely assessment includes material in terms of completeness, breadth, depth and accuracy of the material in the form of a questionnaire for expert. The expert is an expert in the field of Al-Qur'an who has a background as a caretaker of the Tahfidz pesantren who is also the coordinator of the National MTQ jury. Validation of teaching materials in this study was carried out by KH. Muhammad Fathoni Dimyathi, LC .. The results of the validation of the instructional materials by the expert scored a score of 55 of the maximum value of 80 or $68 \%$ validity which also means that it is quite valid, but 
requires revision and provides notes for the substitution of examples that are not in accordance with the Arabic rules on the material cursive letters

b) Experts Assessment of Learning Media

The assessment of instructional media experts in this study includes presentation in terms of engineering, feasibility and graphics. The learning media expert in this study is Ust Bairus Salim M.PdI who has an academic background in post graduate/S2 and is taking this doctoral program as a champion in the final of the Learning Innovation (Inobel) competition in 2017. Judging results get a score of 42 from a maximum score of 65 or earn $64 \%$ meaningful validity is quite valid but requires revision. also notes that in the harmony of the contents which are considered too monotonous, it is necessary to re-touch so as not to appear boring.

4) Expert Assessment 2

a) Expert Assessment Material

In the second assessment, after the revision is made, the material expert re-evaluates the results of a score of 64 from a maximum value of 80 or $80 \%$ validity which also means the teaching material has been declared valid and ready to be tested.

c) Experts Assessment of Media

Revisions have been made in accordance with media expert input, so a second assessment is carried out that gets a score of 50 from a maximum score of 65 , or $76 \%$ validity which also means valid and is ready to continue in the trial.

\section{Effectiveness of Teaching Materials}

a. Product Trial (Implementation)

In conducting product trials conducted by pretest and posttest, the material chosen to be tested in a random way as in the entire teaching material was only taken 3 material, 1 material from each volume. The effectiveness of teaching materials would be measured and adjusted according to the minimum completeness criteria (KKM) of the Griya Al-Qur'an, which is 75 (seventy five).

1) Field Trial 1 
The first field trial was carried out as a preliminary reference whether teaching materials were worthy of a large trial. The first trial was taken from a small class of 9 people. The material tested was the introduction of Sho Dho, Qolqolah and Waqof tasydid with the following results:

Table 9

Trial Value 1

\begin{tabular}{|l|c|c|}
\hline & Pre-test & Pos-test \\
\hline Average & 68 & 78 \\
\hline Many Students Complete & 3 & 7 \\
\hline Completed Student Presentation & $33 \%$ & $78 \%$ \\
\hline Presentation of Unfinished Students & $67 \%$ & $22 \%$ \\
\hline
\end{tabular}

Before learning, the percentage of students who completed was 33\%. This meant that most students did not have an understanding of the material to be studied. In the posttest results, there were 7 students who completed the percentage of completeness by $78 \%$. Of these percentages, most students have reached the Minimum Completeness Criteria (KKM) set by the Griya Al-Qur'an, which was 75. Therefore the developed teaching material was categorized as good so that teaching material can be said to be effective.

2) Field Trial 2

The second field trial was carried out with the same purpose and technicality, but in this advanced trial the scale was larger, there were 24 students measured by the following results:

Table 10

Trial Value 2

\begin{tabular}{|l|c|c|}
\hline & Pre-test & Pos-test \\
\hline Average & 69 & 81 \\
\hline Completed Many Students & 8 & 19 \\
\hline Completed Student Presentation & $33 \%$ & $79 \%$ \\
\hline Presentation of Unfinished Students & $67 \%$ & $21 \%$ \\
\hline
\end{tabular}


Before learning, the percentage of students who completed was 33\%. which meant that most students had not understood the material to be studied. In the results of the posttest it was seen that there were 19 students who completed with a percentage of completeness of $79 \%$. Of these percentages, most students had reached the Minimum Completeness Criteria (KKM) set by the Griya Al-Qur'an, which is 75 . Therefore the developed teaching material was categorized as good so that teaching material can be said to be effective.

\section{b. Evaluasions Steps (Evaluation)}

In this stage the evaluation was carried out in a formative manner because it was directly related to each stage of development and not the last stage, at this stage the evaluation was also carried out by taking a response at the implementation stage which was used to refine it according to the existing input so that the instructional material meets reliability and effectiveness .

\section{CONCLUSSION}

From the results of research and development that has been done, the following conclusions can be drawn:

1. Al-Qur'an learning should pay attention to 7 components of learning, namely:

a. Learning objectives, the Griya Al-Qur'an's objectives already exist and are listed in each learning program

b. Material, materials are arranged based on needs such as leveling of the tahsin, tartil and tahfidz classes whose materials have been opened.

c. Students, in accepting Griya Al-Qur'an students receive a minimum age of 17 years and there is no maximum limit

d. Teacher, the standard of teacher used is at least equivalent to high school, preferably those who have a stratum 1 and also have memorization of at least 15 juz

e. Method, use the SUBUH Approach (greetings, repeat, give, test and hamdalah)

f. Tools, learning and supporting tools are also very much concerned by the Griya Al-Qur'an

g. The scoring system, daily and periodic assessment uses a scale of 60-90 and determines the value of the KKM 75. 
2. In developing this teaching material using ADDIE Model

a. Analyze the results of a revised focus on adding harrah kasrah material and dhammah in volume 1 and also changing the paper size

b. Design by making a re-design of the material based on the results of the analysis and preparing the Mushaf Madinah printing software along with the Ottoman Hafs V09 font,

c. Development by carrying out what has been designed and inviting material experts and instructional media experts to test validity with the results of the values of each expert $80 \%$ and $76 \%$ which means valid.

3. To measure effectiveness, of course through the next ADDIE stage, namely:

a. Implementation by conducting a trial with a pretest result of $33 \%$ and postes of $79 \%$ which means that this teaching material is effective

b. Evaluation, by evaluating each stage of development.

\section{E. REFERENCE}

Ahmad, Abu dan Ahmad Rohani. Pengelolaan Pengajaran, Jakarta: Rineka Cipta, 1991

Amed,Muhammad. (Buta Huruf Al-Qur'an di Indonesia, Sungguh Menyedihkan), https://www.kompasiana.com/alwaysmuhammad 2017 .

Arikunto, Suharsimi . Dasar-Dasar Evaluasi Pendidikan, Jakarta : Bumi Aksara, 2002.

Arikunto,Suharsimi Prosedur Penelitian Suatu Pendekatan Praktik (Edisi Revisi IV) . Jakarta: Rineka Cipta, 2006.

Bahri,Saiful. (Ternyata Hanya 0,5 Persen Masyarakat Indonesia yang Bisa Baca AlQuran), dalam https://www.dakwatuna.com/2014/06/16/53213 2017.

Dokumen Griya Al-Qur'an ,Workshop Griya Al-Qur'an Surabaya, 2014,

Dokumen Griya Al-Qur'an Hasil placementes siswa Griya Al-Qur'an Surabaya, Surabaya:2017.

Dokumen Griya Al-Qur'an Hasil Workshop Guru Griya Al-Quran Surabaya, Surabaya:2015

Masruri, Imam. Wawancara Griya Al-Qur'an, Surabaya: 2017.

Moleong,Lexy,Metodelogi Penelitian Kualitatif ,Bandung: Remaja Rosda Karya 2008 
Sophya, Ida Vera \& Saiful Mujab, Metode Baca Qur'an, Jurnal Elementary, Vol 2, 2014

Sukmadinata,Nana Syaodih. Pengembangan Kurikulum Teori dan Praktik Bandung: PT Remaja rosda karya, 2015.

Surakhman,Winarno. Pengantar Pendidikan Ilmiah, Bandung: Tarsito, 1985.

Tolchah,Moch. Filsafat Pendidikan Islam:Konstruksi Tipologis dalam Pengembangan Kurikulum, Jurnal Tsaqafah, Vol II No 2, 2014.

Trianto, Metode Pembelajaran Terpadu, Jakarta: Prestasi Pustaka, 2007.

http://fath-multimedia.blogspot.com/2012/11/mushaf-quran-madinah-versi-

komputer.html 